Tạp chí Khoa học và Công nghệ biển T10 (2010). Số 3. Tr 89 - 95

\title{
TOXICITY OF SOME MARINE SNAILS RESPONSIBLE FOR RECENT FOOD POISONINGS IN VIETNAM
}

DAO VIET HA

Viện Hải dương học

SHIGERU SATO

Trường Đại học Kitasato, Nhật Bản

\begin{abstract}
Summary: During the years of 2006 - 2007, about five food poisoning cases with fatalities caused by marine snails reported in coastal areas of Vietnam. From stock over of poisoning materials from three out of five cases, causative species were identified as Nassarius papillosus, Nassasius (Alectrion) glans glans, N. (Zeuxis) comptus and Natica (Natica) fasciata. These species also caused poisonings in several countries such as Japan, the Philippines, Brunei and Taiwan.

High level of tetrodotoxin was found in the specimens of $N$. papillosus as the causative component for food poisoning with three patients including two deaths on October 17, 2006 in Quang Ngai province. In contrast, no tetrodotoxin was detected in three other snail species which were eaten at the poisonings on December 17, 2007 in Ninh Thuan province and December 27, 2007 in Binh Thuan province.

Although the origin of tetrodotoxin in marine snails has not been clarified yet, it is urgently necessary to warn potential risks from marine snails to public as some of them may become suddenly toxic with unknown mechanism.
\end{abstract}

Keywords: Poisonings, marine snails, Nassasius, Natica, tetrodotoxin.

\section{INTRODUCTION}

Among several marine snails, some species belonging to the genus Conus have been known as venomous as they cause envenomation by injecting toxins to human through sting (Halstead, 1988). In addition, some marine snails become toxic occasionally and cause human poisonings. Poisonings by eating marine snails were reported in Japan [Hashimoto, 1979], Philippines, Brunei (Meds, 2002), Malaysia (Kan et al., 1986), Taiwan (Yang et al., 1995) and French Polynesia (Gatti et al., 2008). Most of the toxic species belong to Turbinidae, Trotridae, Cymatidae, Olividae and Aplysiadae families, 
which were usually eaten, but become toxic accidentally, unexpectedly and occasionally in certain areas (Meds, 2002).

The responsible toxin in gastropods was reported as tetrodotoxin (TTX) and paralytic shellfish poisoning (PSP) toxins (Meds, 2002; Hwang et al. 2003). However, origin and mechanism of toxin accumulation in them have been not clear. Furthermore, not all individual of the same species, even caught at same location, possess toxicity. Individual variation of toxicity is very large.

During the years of 2006 - 2007, about five food poisoning cases with fatalities by marine snails were reported in coastal areas of Vietnam. Here we introduce the cases of food poisonings due to marine snails as well as preliminary result of toxin analysis from stock over of poisoning materials from three out of the five poisoning cases in Vietnam.

\section{POISONING CASES}

\section{Case 1}

On October 17, 2006, in Quang Ngai Province, three fishermen got poisoning after eating about $500 \mathrm{~g}$ of barbecued marine snails caught by themselves from the coastal areas. About 30 minutes after eating, all of them felt tingling on lips and mouth, difficult to breath and paralysis. Two victims in the same family died within two hours after showing the first symptom.

\section{Case 2}

On December 17, 2007, in Ninh Chu Village, Khanh Hai Commune, Ninh Hai Province, five peoples in one family including two children got poisoning after eating marine snails caught from coastal areas by themselves. All of them showed symptoms of dizziness, tingling on lips and tongue, and convulsion. They were sent to a hospital in time and recovered one day later.

\section{Case 3}

On December 27, 2007, in Duc Long Ward, Phan Thiet Town, Binh Thuan Province, four out of five peoples, who ate steamed marine snails caught from the coast, got poisoning and one of them died. Poisoning symptoms appeared 4 - 6 hours after eating were nausea, vomiting, dizziness, and tingling on tongue. 


\section{MATERIALS AND METHODS}

\section{Specimens of snails}
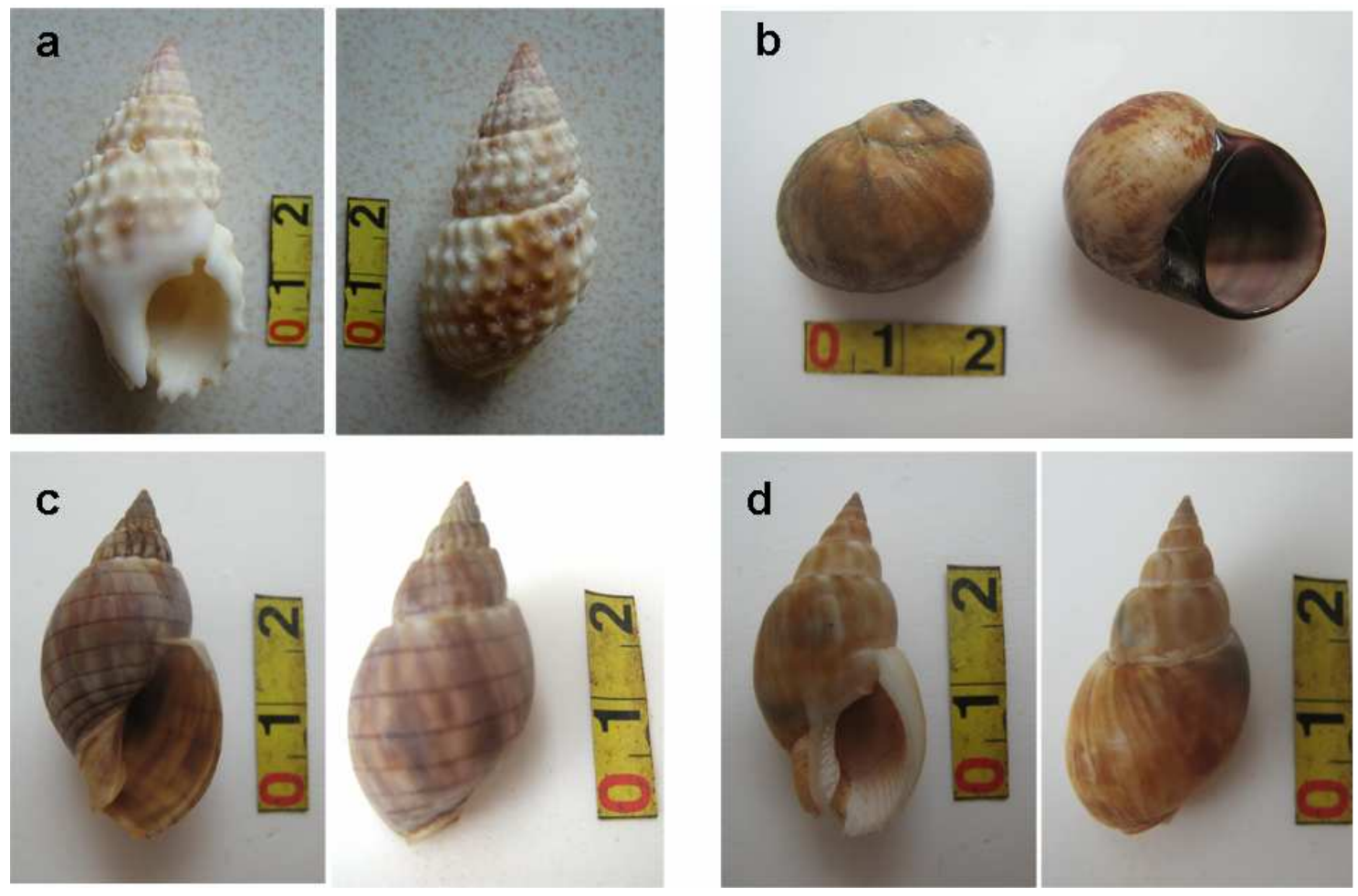

Figure 1: Causative marine snails in Vietnam a: Nassarius (Alectrion) papillosus; b: Natica (Natica) fasciata; c: Nassasius (Alectrion) glans glans;

d: Nassasius (Zeuxis) compus

Snail samples from three poisoning cases, one cooked specimen (5,6 g whole body) of Nassarius papillosus (fig. 1a) from poisoning case 1, 70 uncooked specimens of Natica fasciata (3.3 $\pm 0.5 \mathrm{~g}$ of whole body ) (fig. 1b) from poisoning case 2, and three cooked specimens $(2.7 \pm 0.5 \mathrm{~g}$ of whole body) including one specimens of Nassasius glans glans (fig. 1c) and two specimens of Nassasius compus (fig. 1d) from poisoning case 3 were kept frozen, and sent to the Laboratory of Biochemistry, Institute of Oceanography, Nha Trang, Vietnam. Species identification was carried out.

\section{Toxin analysis}

Due to symptoms of victims which characterized by paralysis, toxin in these poisoning snails is highly suspected as TTX or PSP toxins, therefore these toxins are 
targeted in our analysis. The soft tissue of each specimen was homogenized individually with 4 times volumes of $1 \%$ acetic acid, boiled for 5 minutes, and centrifuged (3000 g, 30 min). The supernatant thus obtained was used as the extract of which one $\mathrm{mL}$ is equivalent to $0.2 \mathrm{~g}$ of the tissue. TTX and its derivatives in the extracts were analyzed by HPLC according to Yotsu et al. (1989). PSP toxins were also analyzed by HPLC according to Oshima (1995). Authentic standard of TTXs (TTX, 4-epiTTX and 4,6-anhTTX mixture) was prepared from the toxic liver of Japanese puffer Takifugu paradalis (Kodama and Ogata, 1984). Standard PSP toxins containing C1+C2, GTX1-4 mixture, STX, dcSTX and neoSTX were a gift from Prof. Dr. Oshima of Tohoku University. The toxicity was calculated based on the specific toxicity of each TTX component (Nakamura and Yasumoto, 1985) and PSP toxins (Oshima, 1995), and express as mouse unit (MU) in which one MU is a toxin dose to kill a $20 \mathrm{~g}$ male mouse (ddY strain).

\section{RESULTS}

\section{Case 1}
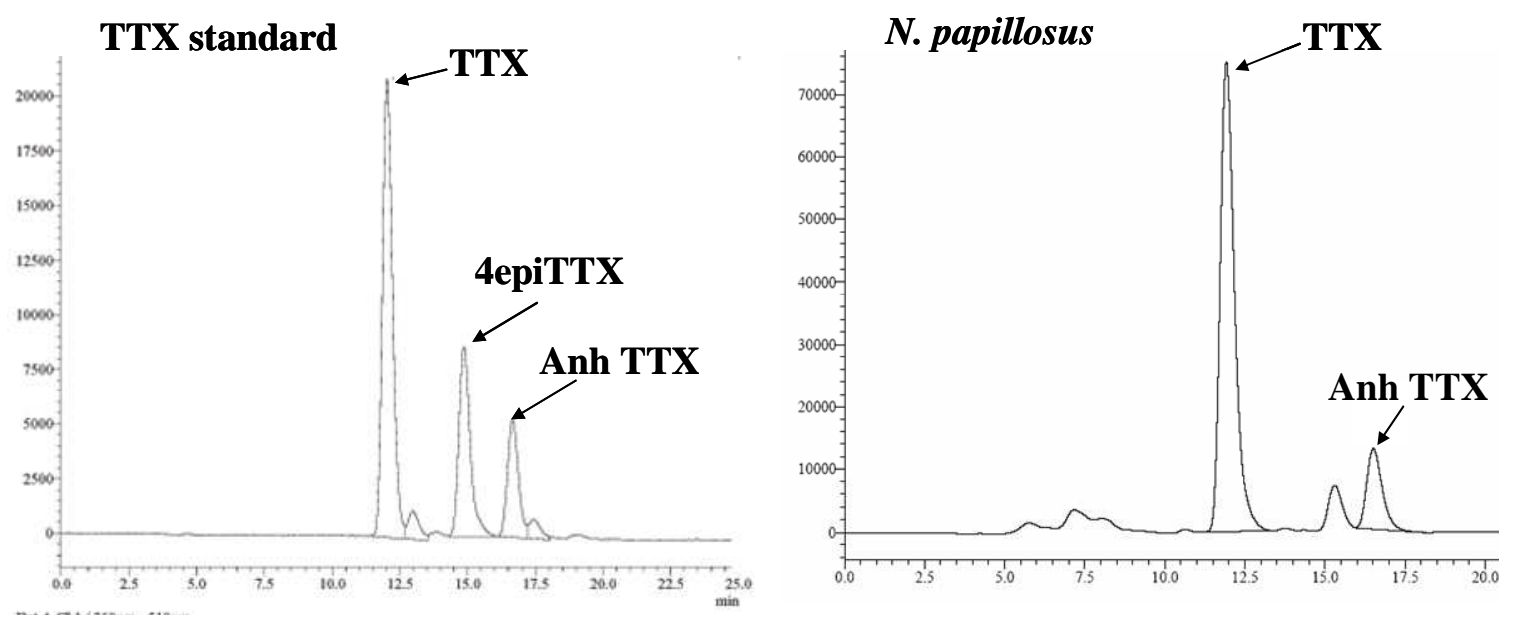

Figure 2: HPLC chromatogram of TTX in N. papillosus

No PSP toxin was detected in the extract, but TTX and anhydro TTX were detected by HPLC (fig. 2). The toxicity of the toxic specimen calculated from specific toxicity of each toxin component expressed in mouse unit (MU), was $70 \mathrm{MU} / \mathrm{g}$ soft tissues. In addition, there was a pick which showed a retention time closed to which of 4-epimer 
TTX standard. However, the different between this peak and 4-epimer TTX standard is larger than $2 \%$, therefore, the peak was not recognized as 4 epimer TTX.

\section{Case 2 and case 3}

In HPLC analysis, low concentrations of TTXs and saxitoxins (STXs) were detected in the extracts. Toxicity calculated from HPLC results was less than $10 \mathrm{MU} / \mathrm{g}$ (data not shown in the paper).

\section{DISCUSSION}

TTX in gastropods was found by several research groups (Noguchi et al., 1984; Hwang et al, 2005; Huang et al., 2008). The remaining specimen of poisoning case 1 showed not high toxicity to compare with toxic snail species reported in Japan, which exhibited 4,290 MU/g (Taniyama et al., 2008), but was more than the safety consumption level of TTXs (10 MU/g) suggested in Japan (Kodama and Sato, 2005), so still enough to cause human food poisoning. Based on the small amounts of TTXs and STXs detected in all specimens were provided from poisoning case 2 and case 3, it is hard to explain food poisonings as these specimens may be considered as non-toxic. The present result is different from those analyzed on Nassasius sp. from Japan and Taiwan (Hwang et al, 2005; Huang et al., 2008), which was reported extremely high amount of TTX in the same species. Considering that the toxicity in marine snails has very large individual variation, for example, toxicity of Alectron glans in Japan could be ranged from 16 - 15,200 MU/g (Taniyama et al., 2008), it is suggested that the toxicity of snail specimens which victims ate must be much higher than those examined in this study.

Further studies on the distribution of toxic snails and the mechanism of toxin accumulation in the snails are necessary for public awareness. It is urgent necessary to announce about potential risks from marine toxic snails to public as some of them may become toxic with unknown mechanism. It is should not eat any marine snail which was recorded as poisonous in other areas, or any strange marine snails.

Acknowledgement: We would like to thank Mr. Bui Quang Nghi, deputy head of Department of Museum and Conservation, Institute of Oceanography, Vietnam for species identification of snails. Also, our thank to Prof. Dr. Masaaki Kodama, School of Biosciences, Kitasato University and Prof. Dr. Yasuwo Fukuyo, Asian Natural Environmental Science Center, The University of Tokyo, Japan for revising of our manuscript. 


\section{REFERENCES}

1. Gatti C., E. Oelherb, A.M. Legrand, 2008. Severe seafood poisoning in French Polynesia: A retrospective analysis of 129 medical files. Toxicon 51: 746-753.

2. Halstead B.W., 1988. Poisonous and Venomous marine animals of World (2nd revised edition). Princeton: NJ. Darwin press.

3. Hashimoto Y., 1979. Marine toxins and other bioactive metabolites. 1979. Jap. Soc. of Science. Tokyo.

4. Huang H.N., J. Lin, H.L. Lin, 2008. Identification and quantification of tetrodotoxin in the marine gastropod Nassarius by LC-MS. Toxicon. 51: 774-779.

5. Hwang D.F., L.C. Lin and S. Deng, 1992. Occurrence of a new toxin and tetrodotoxin in two species of the gastropod mollusc Nasariidae. Toxicon 30(1): 416.

6. Hwang P. A., Y. H. Tsai, Y. H. Lu, D. F. Hwang, 2003. Paralytic toxins in three new gastropod (Olividae) species implicated in food poisoning in southern Taiwan. Toxicon. 41: 529-533.

7. Kan S.K.P., N. Singh, M.C.K. Chan, 1986. Olive va vidua fulminans, a marine mollusc, responsible for five fatal cases of neurotoxic food poisoning in Sabah, Malaysia. Trans. Roy. Soc. Trop. Med. Hyg. 80: 64.

8. Kodama M., Sato S., 2005. Fugudoku. Manual for food safety (Shyokuhin Eiseikensasisin): 661-666.

9. Kodama M., T. Ogata, K. Kawamukai, Y. Oshima and T. Yasumoto, 1984. Toxicity of muscle and other organs of five species of puffer collected from the Pacific coast of Tohoku area of Japan. Bull Jap Soc Sci Fish. 50: 703-706.

10. Mebs D., 2002. Venomous and Poisonous Animals. Medpharm Scientific Publishers Stuttgard. CRC Press, Germany.

11. Nakamura M., Yasumoto T., 1985. Tetrodotoxin derivatives in puffer fish. Toxicon. 23: 271-276.

12. Noguchi T., J. Maruyama, H. Narita and Y. Hashimoto, 1984. Occurrence of tetrodotoxin in the gastropod mollusc Tutufa lissostoma (Frog shell). Toxicon. 22(2): 219-226. 
13. Oshima Y., 1995. Post-column derivative HPLC methods for Paralytic Shellfish Poisons. In: Manual on Harmful Marine Microalgae (Hallegraeff G.M., D.M. Anderson and A. Cembella, eds) 81-94. IOC of UNESCO, Paris.

14. Taniyama S., Y. Isami, T. Matsumoto, Y. Nagashima, T. Takatani, S. Arakawa, 2008. Toxicity and toxin component of Alectrion glans in relation to a food poisoning occurred in Nagasaki. Abstracts for the Annual Meeting of the Japan. Soc. Fish. Sci.102.

15. Yang C.C., K.C. Han, T.J. Lin, W.J. Tsai, J.F. Deng, 1995. An outbreak of tetrodotoxin poisoning following mollusc consumption. Hum. Exp. Toxicol. 14: 446.

16. Yotsu M., Endo A., Yasumoto T., 1989. An improved tetrodotoxin analyzer. Agric. Biol. Chem. 53: 898-895.

\title{
ĐộC TÍNH CỦA MộT SỐ LOÀI ỐC BIỂN LIÊN QUAN ĐẾN CÁC VỤ NGộ ĐộC GẦN ĐÂY TẠI VIẸTT NAM
}

\author{
ĐÀO VIẸTT HÀ, SHIGERU SATO
}

Tóm tắt: Có ít nhất 5 vu ngộ độc thực phẩm do ăn ốc biển được ghi nhận tại các vùng ven biển Việt Nam trong các năm 2006-2007. Mẫu vật ốc biển còn sót lại của 3 trong số 5 vụ ngộ độc này được xác định thuộc các loài Nassarius papillosus, Nassasius (Alectrion) glans glans, N. (Zeuxis) comptus và Natica (Natica) fasciata. Đây cũng là nhũng loài gây ra nhũng vu ngộ độc tương tụ ở một số Quốc gia khác nhu Nhật Bản, Phi-lip-pin, Brunây và Đài Loan.

Bằng phuơng pháp sắc ký lỏng hiệu năng cao (HPLC), đã xác định được hàm luợng khá cao độc tố tetrodotoxin (TTX) trong mẫu vật của loài $N$. papillosus gây ra vu ngộ độc cho 3 nạn nhân (2 tư vong) ngày 17 - 10 - 2006 tại tỉnh Quảng Ngãi. Ngược lại, không tìm thấy sự có mặt của độc tố TTX trong 3 loài ốc biển nghi ngò̀ gây ra 2 vụ ngộ độc khác vào 17 - 12 - 2007 tại Ninh Thuận và 27 - 12 - 2007 tại Bình Thuận.

Mặc dù nguồn gốc của độc tố TTX trong ốc biển vẫn còn chua được biết đến, nhung một số loài ốc biển có thể trở nên độc một cách bất thuờng vào một thời điểm nhất định nào đó, do vậy cần thiết phải có cảnh báo về nguy co ngộ độc tù̀ nhũng loài sinh vật này.

Tù khóa: ngộ độc thực phẩm, ốc biển, Nassarius, Nassasius, Natica, tetrodotoxin.

Ngày nhận bài: 30 - 8 - 2009

Ngưòi nhận xét: TS. Phạm Xuân Kỳ 